\title{
Advances in the rhizosphere: stretching the interface of life
}

\author{
Liesje Mommer • Philippe Hinsinger • \\ Claire Prigent-Combaret • Eric J. W. Visser
}

Received: 5 July 2016 / Accepted: 24 August 2016/Published online: 1 September 2016

(C) Springer International Publishing Switzerland 2016

\begin{abstract}
"Stretching the interface of life" was the motto of the international Rhizosphere 4 Conference in Maastricht in June 2015. This motto reflects the key position that the rhizosphere has in each terrestrial ecosystem. Belowground interactions between plant roots, soil microbes and the abiotic soil environment drive important ecosystem processes such as productivity (Reinhart et al. 2010; Schnitzer et al. 2011), biogeochemical cycling (de Vries et al. 2013), and tolerance to biotic and abiotic stresses (Berendsen et al. 2012; Visioli et al. 2015). At the same time, this motto reflects the highly dynamic nature of the rhizosphere (Hinsinger et al. 2009; Philippot et al. 2013). The rhizosphere is a multifaceted, complex 'melting pot' of components and processes
\end{abstract}

Responsible Editor: Hans Lambers .

L. Mommer $(\bowtie)$

Nature Conservation and Plant Ecology Group, Wageningen University, PO box 47, 6700 AA Wageningen, The Netherlands e-mail: Liesje.Mommer@wur.nl

P. Hinsinger

INRA, UMR Eco \& Sols, Place Viala, 34060 Montpellier Cedex 1, France

C. Prigent-Combaret

Ecologie Microbienne, CNRS UMR5557, INRA UMR1418, Université Lyon 1, Université de Lyon, F-69622 Villeurbanne, France

\section{E. J. W. Visser}

Department of Experimental Plant Ecology, Radboud University Nijmegen, Heyendaalseweg 135, 6525 AJ Nijmegen,

The Netherlands affecting plant growth and development, and thus ecosystem functioning. One main component of the rhizosphere is the root microbiome, which are all microorganisms inhabiting the root or rhizosphere (Lundberg et al. 2012; Mendes et al. 2013). Root exudates, i.e., a variety of small molecules excreted by plant roots are another important component in the rhizosphere (Bais et al. 2006; Hinsinger et al. 2009; Li et al. 2007; Suriyagoda et al. 2012). Plant roots are able to regulate these exudates and influence their root microbiome accordingly (Haichar et al. 2008). However, this is not a unidirectional path as the root microbiome also produces many metabolites and thus also able to affect the composition of the chemical cocktail in the rhizosphere.. These mutual interactions ultimately affect nutrient availability for all partners (Lambers et al. 2008), plant health (Berendsen et al. 2012) and root-root interactions (Semchenko et al. 2014), cascading into ecosystem functions such as productivity (Latz et al. 2012; Li et al. 2016) and soil formation (Lambers et al. 2009; Keiluweit et al. 2015; Lange et al. 2015). The challenge now is to reveal the functionality of these multifacetted interactions between plant roots, root exudates, microbial metabolites, the root microbiome and the soil..Management of this multicomponent complexity of the rhizosphere and its relationship to soil fertility will become crucial in order to maintain food production with reduced fertiliser and pesticide inputs (Bakker et al. 2012).

The rhizosphere, initially formulated by Hiltner as the 'soil influenced by roots' (Hiltner 1904; Hartmann et al. 2008) developed into a booming research field 
where scientists approach this specific zone around the plant root from different angles. The fourth international Rhizosphere Conference, following earlier successful meetings in this series (Hinsinger and Marschner 2006; Jones and Hinsinger 2008; Jones 2009; Tibbett et al. 2012), clearly reflected this multi-disciplinarity: 18 sessions covering molecular biology, agronomy, microbiology, genomics, ecology, soil science, chemistry, etc., attracted more than 550 scientists from 46 countries to advance our understanding of the rhizosphere. This multi-disciplinarity is also reflected in this Special Issue of Plant and Soil, highlighting the state-of-the-art of rhizosphere research as presented at the Rhizosphere 4 Conference. The resulting set of papers comprises a wide range of topics that include root traits and the root microbiome, nutrient acquisition and nutrient cycling, water uptake, and rhizosphere signaling. This special issue not only covers experimental studies, but also provides an update of the state-of-art in modelling (Ahmed et al. 2016; Roose et al. 2016; Vetterlein and Doussan 2016), with as highlight the Marschner Review on imaging and modelling of rhizosphere processes (Roose et al. 2016). This Marschner Review summarizes cutting-edge knowledge of structural and chemical imaging of rhizosphere processes in the framework of multiscale mathematical image-based modelling. Roose et al. (2016) emphasize the need to integrate structural and chemical images through modelling explicitly root and microbe mediated processes occurring at the porescale, to fully understand the intimate functioning of the highly dynamic and heterogeneous micro-environments that make up the rhizosphere, at the heart of root-soil interactions.

\section{Linking root traits to function}

Roots have long been 'the hidden half' of plants. Consequently, the true functionality of root characteristics (i.e., traits) for important processes such as nutrient or water uptake, plant performance, plantplant interactions and ecosystem functioning remains to be unravelled. For example, ecologists have focused on the ability of roots to selectively forage for nutrients as a key trait determining plant performance and competitive ability (Fransen and de
Kroon 2001; Hodge et al. 1999; Kembel and Cahill 2005), but these efforts have not yielded unequivocal evidence for selective root placement being a crucial trait. Instead, plant performance, and particularly plant competitive ability, appear to be linked to a range of root traits, which probably also depend on the biotic and abiotic environment (Mommer et al. 2011a; Rajaniemi 2007; Schröder-Georgi et al 2015; Siebenkäs and Roscher 2016). Recently, the research on root traits has widened by focussing on a larger variety of traits, such as root length density, mean rooting depth, specific root length, and carbon to nitrogenratio. This broadened view allowed root traits to be placed in ecological frameworks, determining their role in plant performance and competitive interactions (Fort et al. 2013; Roumet et al. 2006; Schröder-Georgi et al 2015), ecosystem functioning (Bardgett et al. 2014; Cong et al. 2014) and the resource economics spectrum (Roumet et al. 2016; Weemstra et al. 2016). The study of (Ravenek et al. 2016) in this issue reflects this new direction, as it links root traits to pairwise interactions in eight grassland species, in homogeneous and heterogeneous nutrient conditions. In the short term, competitive success of a species was related to fast growth and a high root length density, irrespective of nutrient distribution. The work of Wang et al. (2016) also focusses on the role of root traits in competitive interactions, by exploring belowground interactions of graminoids and shrubs in the Siberian tundra. Differentiation in phenology (timing of root growth) and vertical distribution between the two functional groups are likely key determinants of the competitive outcome. Two other papers on root traits in this special issue investigate the relationship between root traits and phosphorus (P) acquisition. Haling et al. (2016) compare root growth and allocation to $\mathrm{P}$ efficiency of several legume species, using the grass Dactylis glomerata as a baseline. Species that had a lower external critical $P$ requirement allocated fewer roots to fertilized patches than those with a higher critical P requirement. The first (e.g., Ornithopus spp.), however, gained their $\mathrm{P}$ share by having a higher $\mathrm{P}$ uptake per unit root mass than the latter. Such findings suggests that root allocation and selective placement in nutrient hotspots may be one way to compete for nutrients, but, alternatively, producing efficient roots at little biomass costs can be 
similarly (or even more) functional (Kembel et al. 2008; Mommer et al. 2011b).

\section{Nutrient acquisition and nutrient cycling}

Plant roots are primarily designed to access belowground resources, on top of providing anchorage, and thereby play a key role in nutrient acquisition and nutrient cycling (Hinsinger et al. 2009; Lambers et al. 2009; Bardgett et al. 2014). A great deal of research has been conducted and published in this domain in the past decades, and a section of the present special issue is dedicated to it. Root traits, such as root length and rooting depth, play a critical role in the uptake of rather mobile resources such as water and nutrients like nitrogen by plants. Higher nitrogen uptake is often linked to increased herbage yield of pastures, as well as to reduced nitrate leaching (Kristensen and ThorupKristensen 2004). Strategic (i.e., delayed) timing of nitrogen application after a harvest of Lolium perenne could thus affect root biomass and herbage yield. De Boer et al. (2016), however, did not find evidence that delayed nitrogen fertilization improves root biomass. Like Lolium perenne, Trifolium repens is also an important species in pastures. Czaban et al. (2016) demonstrates that this species can take up forms of organic nitrogen in hydroponics systems, which indicates that on top of inorganic nitrogen, this species might not only rely on its symbiosis with Rhizobium.

The research field of nutrient acquisition also benefits from current advances in molecular biology. Tanaka et al. (2016) took a mutagenesis approach of a rice cultivar to investigate heritability for micronutrient uptake, such as manganese and zinc, but also for the uptake of hazardous trace metals such as cadmium.

While much of the accumulated knowledge on plant nutrition and on the fate of nutrients in the rhizosphere has been obtained in hydroponics or microcosm experiments with a single crop or cultivar, there is a need to move towards more biodiversity-based agriculture for achieving sustainable intensification of agroecosystem, and thus to embrace the complexity of rhizosphere processes occurring in these systems, e.g. intercropping systems (Li et al. 2007, 2014). Positive plant-plant interactions, such as root-root facilitation, have been shown to play a significant role for $\mathrm{P}$ acquisition ( $\mathrm{Li}$ et al. 2007; Brooker et al. 2015; Li et al. 2016; Zhang et al. 2016). Tang et al. (2016) further demonstrated the greater performance of such intercropping systems compared to single crop systems under field conditions along a P fertility gradient. They showed that the overyielding of the intercrops occurred at all levels of $\mathrm{P}$ fertility, discounting the stress gradient theory predicting more positive plant-plant interactions to occur under low P conditions. Their study showed, however, that, when considering the properties of the rhizosphere, P fertility had a major effect on rhizosphere microbial communities. A rhizosphere effect, namely the increase of microbial biomass $\mathrm{C}$ in the rhizosphere, occurred only at high $\mathrm{P}$, as rhizosphere microbial communities were too much P-limited at the lower end of the fertility gradient. They also showed that intercropping had a significant effect on microbial properties of the rhizosphere only at the upper end of the fertility gradient. Soil fertility thus has a significant impact on the outcome of root-root and root-soil interactions, which needs to be further investigated in various types of ecosystems.

Soil fertility is linked to carbon sequestration via soil organic matter, and the most dynamic portion of soil organic matter, namely dissolved organic matter circulating in soils. Changes in nutrient availability and uptake may affect dissolved organic matter, for example via changes in decomposition rate. Robroek et al. (2016) studied the effect of the functional types of vascular plants on microbial enzymatic activity and the composition of dissolved organic matter. They concluded that global change affects the abundance of vascular plants in peat ecosystems, which in turn increases soil microbial activity and, hence, may affect $\mathrm{C}$ losses from such ecosystems.

\section{Water relationships in the rhizosphere}

Rhizosphere is more than interactions between roots and nutrients, since water is also an essential driver. This special issue focusses on two aspects of water relationships in the rhizosphere: the impact of the root age and function (Iversen 2010; 2014) on root water uptake and rhizosphere biophysics, and the need for functional structural modelling to integrate all these aspects in order to understand the fate of water in the root environment (Vetterlein and Doussan 2016). Currently, the theoretical developments and increase in computational power allow experimental quantification of properties such as hydraulic conductance variation, which is still 
ahead of experimental evidence backing up the models. There is indeed surprising scarcity of data on root age distribution with depth, and on the fate of roots and root functioning, especially in annual crops. The functional properties possibly impacting water relationships in the rhizosphere that are affected by root age are however numerous: from axial hydraulic conductance, occurrence of apoplastic barriers, secondary growth or distribution of aquaporin expression to decay of root cortical cells and mucilage production (Vetterlein and Doussan 2016). Ahmed et al. (2016) start filling this gap by measuring the water repellency of root-exuded mucilage (i.e., plant specific polysaccharides) on maize plants under different soil conditions. This work, based on a combination of measurements and modelling, shows that, beyond a threshold concentration that decreased with increasing particle size and decreasing matric potential, root mucilage can turn the rhizosphere hydrophobic, ultimately resulting in a dramatic reduction of water flow at the root-soil interface. The work by Ahmed et al. (2016) is pledging for more work in this field of rhizosphere biophysics, given its major impact on the fate of water, and thus nutrients and other solutes in the root environment, at various scales from local up to the whole root system scale.

\section{Communication in the rhizosphere}

Signaling in the rhizosphere can be divided into four categories: among plants, among microbes, from plants to microbes, and from microbes to plants (van Dam and Bouwmeester 2016; Venturi and Keel 2016). The Rhizosphere 4 conference points out the huge diversity of signal molecules involved and summarized here briefly. In this special issue, we more particularly focus on the modulation of plant metabolism by microbes, with a specific highlight on the impact of bacterial inoculation on plant volatiles (including ethylene) and as a consequence plant stress alleviation.

One main mechanism of communication between bacteria at both intraspecies and interspecies levels is known as quorum-sensing. It allows bacterial populations to synchronize their behaviour to cell density, through the exchange of a huge range of signal molecules (Boyer and Wisniewski-Dyé 2009; Venturi and Keel 2016). Quorum-sensing is involved in the regulation of several bacterial processes, such as biofilm formation, virulence in pathogenic bacteria, production of antimicrobial compounds by biocontrol plant growthpromoting rhizobacteria (PGPR) (Boyer and Wisniewski-Dyé 2009; Hartmann and Schikora 2012). Direct effects of bacterial quorum-sensing signals on plants also exist (Ortíz-Castro et al. 2009; Kakkar et al. 2015). When present at low concentrations, some antibiotics can also be involved in communication between microbial populations, triggering gene expression regulation in the exposed bacterial cells (Combes-Meynet et al. 2011). By being able to affect gene expression even across interkingdom domains, microbial emitted signals have thus crucial roles in shaping rhizosphere microbial communities and controlling their functioning.

Interactions between microbes are regulated by root exudates, having a high diversity of primary and secondary metabolites (sugars, organic acids, amino-acids, phenolic or terpenoid compounds) (van Dam and Bouwmeester 2016). With the progress in metabolomics methods coupled to multivariate analyses (van Dam and Bouwmeester 2016) and metabolic networks identification, major advances were recently made regarding the characterization of plant root exudate composition and their differences among plant genotypes, environmental conditions or even experimental conditions at harvest (as discussed in a Rhizosphere 4 round table meeting). Exudate molecules can affect the rhizosphere bacterial populations by acting as nutrient or signal molecules. Through their nutritive effects, exudates will affect the structure of soil microbial communities, favoring cell division of bacteria able to catabolize them. Though microbe-plant chemical dialogues are well-known in the case of symbiotic interactions between legumes and nitrogen-fixing rhizobia (Limpens et al. 2015; Li et al. 2016) or in plant mycorrhiza (Parniske 2008), these are less well characterized in plant-PGPR interactions.

Plant-microbe communication involves also a wide range of signaling molecules produced by the microbe partner, some being involved in the direct control of plant growth and development; these include phytohormones like auxin, cytokinin, and gibberellin (Vacheron et al 2013). Other bacterial molecules can trigger induced systemic resistance and improve plant defence against pathogens (Venturi and Keel 2016). Two studies from this special issue focused on the place of ethylene signaling during plant-PGPR cooperation. Ethylene is a plant volatile hormone, which is produced in greater amounts when plants face adverse conditions, and may 
inhibit the growth of plant roots. Ethylene is synthesized from 1-aminocyclopropane-1-carboxylate (ACC) by ACC oxidase. Bacteria that harbor ACC deaminase hydrolyze ACC, leading to a decrease of plant ethylene content and thus to enhanced root growth (Glick et al. 2007). In addition, by lowering the level of ethylene, $\mathrm{AcdS}^{+}$bacteria (AcdS being the gene encoding for ACC deaminase synthesis) can protect the plant against certain damage. Matsuoka et al. (2016) show that ACC deaminase-producing endophytes, isolated from fruits and vegetables (including carrots), are able to modify stress-induced volatile metabolic profiles of carrots, and thereby can modify the flavour of carrots. Volatiles were decreased in the carrot leaves in response to bacterial inoculation and increased in the roots. In particular, green leaf volatiles that derived from linoleic and linolenic acids were reduced in plants inoculated with $\mathrm{AcdS}^{+}$strains. This study suggests that $\mathrm{AcdS}^{+}$bacteria can fine tune the plant defense pathway as well as affects the quality of agricultural products. As the expression of the ACC deaminase synthesis-encoding acdS gene is activated in presence of ACC, the contribution of this bacterial enzymatic activity to stimulation of plant growth depends on the levels of exuded ACC in the rhizosphere. Vacheron et al. (2016) provide evidence that maize genotypes differ in their ability to enhance the expression of the $a c d S$ gene of an inoculated PGPR. When the ethylene pathway is strongly activated by stress conditions, the maize genotype that strongest induced $a c d S$ was the one benefiting from the PGPR inoculation.

\section{Root microbiome}

The description of the root microbiota has received a boost by the development of high-throughput sequencing techniques (Mendes et al. 2013; Pieterse et al. 2016). Initially, the field focussed on Arabidopsis in controlled conditions (Badri et al. 2009; Bulgarelli et al. 2012; Lundberg et al. 2012; Sugiyama et al. 2013) but nowadays the rhizobiome of crop species are also determined, under filed conditions (Bulgarelli et al. 2015; Peiffer et al. 2013). It will now be the challenge to move beyond the 'collection of stamps', i.e. to move from the description of root microbiomes towards the understanding of the functionality for plant performance. Such knowledge is relevant in order to understand belowground plant competitive interactions (Mommer et al. 2016) as well as plant responses under abiotic or biotic stress, in soils with different limiting nutrients (Thomson et al. 2015), or in response to a changing climate. Gschwendtner et al. (2016) described the effect of nitrogen fertilisation on the diversity of bacterial communities. Fertilised soil reduced the incorporation of labelled carbon $\left({ }^{13} \mathrm{C}\right)$ into microbial biomass, specifically in the Proteobacteria and Actinobacteria, suggesting altered composition of rhizodeposits as a function of nitrogen availability (Gschwendtner et al. 2016). Knowledge of the root microbiota will be important for optimization of plant-microbe interactions, which is of interest to breeders and farmers (Bakker et al. 2012; Philippot et al. 2013). An example of this is the selection of the optimal PGPR strain of Bacillus subtilis, a beneficial growth promoting rhizobacterium involved in salt tolerance in the halophyte grass Puccinellia tenuiflora. This study provides physiological and molecular evidence that application of selected bacteria to salt tolerant monocots can ameliorate deleterious effects of high soil saline toxicity (Niu et al. 2016). Stroheker et al. (2016) determined the development of the community structure of dark septate endophytes of the Phialocephala fortiniiAcephala applanata species, being root colonisers in forests. An earlier study had showed that this community was very stable, but an assessment after 10 years showed significant turnover within this species complex.

\section{Outlook}

The Rhizosphere 5 Conference will be held in Saskatoon, Canada, in 2019. The field of the rhizosphere will have further developed by then, with high-throughput sequencing techniques and meta-omics approaches becoming cheaper and more advanced; bioinformatics pipelines developed and made accessible to nonbioinformaticians. Moreover, imaging techniques improve rapidly, and complex functional-structural modelling as well. We expect future studies to make major leaps forward in revealing the functionality of the complex interactions between plant roots, root exudates, microbial metabolites, and root microbiomewithin the context of 'true' soil environments, i.e., in field conditions. The focus of the research will shift to understanding the rhizosphere 'melting pot' in the real world: managing the rhizosphere will be crucial to advance agricultural practices and move towards a more 
biodiversity-based agriculture. The increasing demand for food with reduced inputs of fertilisers and pesticides is pressing. Similarly, the sustainability of natural ecosystems is of great importance, where rhizosphere management will be crucial in mitigating climate change and maintaining ecosystem functioning.

\section{References}

Ahmed MA, Kroener E, Benard P, Zarebanadkouki M, Kaestner A, Carminati A (2016) Drying of mucilage causes water repellency in the rhizosphere of maize: measurements and modelling. Plant Soil. doi:10.1007/s11104015-2749-1

Badri DV, Quintana N, El Kassis EG, Kim HK, Choi YH, Sugiyama A, Verpoorte R, Martinoia E, Manter DK, Vivanco JM (2009) An ABC transporter mutation alters root exudation of phytochemicals that provoke an overhaul of natural soil microbiota. Plant Physiol 151: 2006-2017

Bais HP, Weir TL, Perry LG, Gilroy S, Vivanco JM (2006) The role of root exudates in rhizosphere interations with plants and other organisms. Annu Rev Plant Biol 57: 233-266

Bakker MG, Manter DK, Sheflin AM, Weir TL, Vivanco JM (2012) Harnessing the rhizosphere microbiome through plant breeding and agricultural management. Plant Soil 360:1-13

Bardgett RD, Mommer L, De Vries FT (2014) Going underground: root traits as drivers of ecosystem processes. Trends Ecol Evol 29:692-699

Berendsen RL, Pieterse CM, Bakker PA (2012) The rhizosphere microbiome and plant health. Trends Plant Sci $17: 478-486$

Boyer M, Wisniewski-Dyé F (2009) Cell-cell signalling in bacteria: not simply a matter of quorum. FEMS Microbiol Ecol 70:1-19

Brooker RW, Bennett AE, Cong W-F, Daniell TJ, George TS, Hallett PD, Hawes C, Iannetta PPM, Jones HG, Karley AJ, Li L, McKenzie BM, Pakeman RJ, Paterson E, Schöb C, Shen J, Squire G, Watson CA, Zhang C, Zhang F, Zhang J, White PJ (2015) Improving intercropping: a synthesis of research in agronomy, plant physiology and ecology. New Phytol 206:107-117. doi:10.1111 /nph.13132

Bulgarelli D, Rott M, Schlaeppi K, van Themaat EVL, Ahmadinejad N, Assenza F, Rauf P, Huettel B, Reinhardt R, Schmelzer E (2012) Revealing structure and assembly cues for arabidopsis root-inhabiting bacterial microbiota. Nature 488:91-95

Bulgarelli D, Garrido-Oter R, Munch PC, Weiman A, Droge J, Pan Y, McHardy AC, Schulze-Lefert P (2015) Structure and function of the bacterial root microbiota in wild and domesticated barley. Cell Host Microbe 17:392-403

Combes-Meynet E, Pothier JF, Moënne-Loccoz Y, PrigentCombaret C (2011) The Pseudomonas secondary metabolite 2,4-diacetylphloroglucinol is a signal inducing rhizoplane expression of Azospirillum genes involved in plant-growth promotion. Mol Plant-Microbe Interact 24:271-284

Cong WF, Ruijven J, Mommer L, De Deyn GB, Berendse F, Hoffland E (2014) Plant species richness promotes soil carbon and nitrogen stocks in grasslands without legumes. J Ecol 102:1163-1170

Czaban W, Jämtgård S, Näsholm T, Rasmussen J, Nicolaisen M, Fomsgaard IS (2016) Direct acquisition of organic N by white clover even in the presence of inorganic N. Plant Soil. doi:10.1007/s11104-016-2896-Z

de Boer HC, Deru JGC, Hoekstra NJ, van Eekeren N (2016) Strategic timing of nitrogen fertilization to increase root biomass and nitrogen-use efficiency of Lolium perenne L. Plant Soil. doi:10.1007/s11104-016-2917-y

de Vries FT, Thébault E, Liiri M, Birkhofer K, Tsiafouli MA, Bjørnlund L, Jørgensen HB, Brady MV, Christensen S, de Ruiter PC (2013) Soil food web properties explain ecosystem services across European land use systems. Proc Natl Acad Sci 110:14296-14301

Fort F, Jouany C, Cruz P (2013) Root and leaf functional trait relations in Poaceae species: implications of differing resource-acquisition strategies. J Plant Ecol 6:211-219

Fransen B, de Kroon H (2001) Long-term disadvantages of selective root placement: root proliferation and shoot biomass of two perennial grass species in a 2-year experiment. J Ecol 89: 711-722

Glick BR, Cheng Z, Czarny J, Duan J (2007) Promotion of plant growth by ACC deaminase-producing soil bacteria. Eur J Plant Pathol 119:329-339

Gschwendtner S, Engel M, Lueders T, Buegger F, Schloter M (2016) Nitrogen fertilization affects bacteria utilizing plantderived carbon in the rhizosphere of beech seedlings. Plant Soil. doi:10.1007/s11104-016-2888-Z

Haichar FZ, Marol C, Berge O, Rangel-Castro JI, Prosser JI, Balesdent J, Heulin T, Achouak W (2008) Plant host habitat and root exudates shape soil bacterial community structure. ISME J 2:1221-1230

Haling RE, Yang Z, Shadwell N, Culvenor RA, Stefanski A, Ryan MH, Sandral GA, Kidd DR, Lambers H, Simpson RJ (2016) Growth and root dry matter allocation by pasture legumes and a grass with contrasting external critical phosphorus requirements. Plant Soil. doi:10.1007/s11104-016-2808-2

Hartmann A, Schikora A (2012) Quorum sensing of bacteria and trans-kingdom interactions of $\mathrm{N}$-acyl homoserine lactones with eukaryotes. J Chem Ecol 38:704-713

Hartmann A, Rothballer M, Schmid M (2008) Lorenz Hiltner, a pioneer in rhizosphere microbial ecology and soil bacteriology research. Plant Soil 312:7-14

Hiltner L (1904) Über neuere Erfahrungen und Probleme auf dem Gebiete der Bodenbakteriologie unter besonderer Berücksichtigung der Gründüngung und Brache. Arb DLG 98:59-78

Hinsinger P, Marschner P (2006) Rhizosphere-perspectives and challenges - a tribute to Lorenz Hiltner 12-17 September 2004 -Munich, Germany. Plant Soil 283:vii-viii

Hinsinger P, Bengough AG, Vetterlein D, Young IM (2009) Rhizosphere: biophysics, biogeochemistry and ecological relevance. Plant Soil 321:117-152. doi:10.1007/s11104-008-9885-9

Hodge A, Robinson D, Griffiths BS, Fitter AH (1999) Why plants bother: root proliferation results in increased nitrogen capture 
from an organic patch when two grasses compete. Plant Cell Environ 22:811-820

Iversen CM (2010) Digging deeper: fine-root responses to rising atmospheric $\mathrm{CO} 2$ concentration in forested ecosystems. New Phytol 186:346-357

Iversen CM (2014) Using root form to improve our understanding of root function. New Phytol 203:707-709

Jones DL (2009) RHIZOSPHERE 2 international conference, Montpellier, August 2007. Soil Biol Biochem 41:1767-1767

Jones DL, Hinsinger P (2008) Rhizosphere: complex by design. Plant Soil 312:1-6

Kakkar A et al (2015) Xanthomonas campestris cell-cell signalling molecule DSF (diffusible signal factor) elicits innate immunity in plants and is suppressed by the exopolysaccharide xanthan. J Exp Bot 66:6697-6714

Keiluweit M, Bougoure JJ, Nico PS, Pett-Ridge J, Weber PK, Kleber M (2015) Mineral protection of soil carbon counteracted by root exudates. Nat Clim Chang 5:588-595

Kembel SW, Cahill JF (2005) Plant phenotypic plasticity belowground: a phylogenetic perspective on root foraging tradeoffs. Am Nat 216:166-230

Kembel SW, De Kroon H, Cahill JF, Mommer L (2008) Improving the scale and precision of hypotheses to explain root foraging ability. Ann Bot 101:1295-1301

Kidd DR, Ryan MH, Haling RE, Lambers H, Sandral GA, Yang Z, Culvenor RA, Cawthray GR, Stefanski A, Simpson RJ (2016) Rhizosphere carboxylates and morphological root traits in pasture legumes and grasses. Plant Soil. doi:10.1007/s11104-015-2770-4

Kristensen HL, Thorup-Kristensen K (2004) Root growth and nitrate uptake of three different catch crops in deep soil layers. Soil Sci Soc Am J 68:529-537

Lambers H, Raven JA, Shaver GR, Smith SE (2008) Plant nutrient-acquisition strategies change with soil age. Trends Ecol Evol 23:95-103

Lambers H, Mougel C, Jaillard B, Hinsinger P (2009) Plantmicrobe-soil interactions in the rhizosphere : an evolutionary perspective. Plant Soil 321:83-115

Lange M, Eisenhauer N, Sierra CA, Bessler H, Engels C, Griffiths RI, Mellado-Vazquez PG, Malik AA, Roy J, Scheu S, Steinbeiss S, Thomson BC, Trumbore SE, Gleixner G (2015) Plant diversity increases soil microbial activity and soil carbon storage. Nat Commun 6: 6707. doi: $10.1038 /$ ncomms 7707

Latz E, Eisenhauer N, Rall BC, Allan E, Roscher C, Scheu S, Jousset A (2012) Plant diversity improves protection against soil-borne pathogens by fostering antagonistic bacterial communities. J Ecol 100:597-604

Li L, Li SM, Sun JH, Zhou LL, Bao XG, Zhang HG, Zhang FS (2007) Diversity enhances agricultural productivity via rhizosphere phosphorus facilitation on phosphorus-deficient soils. Proc Natl Acad Sci U S A 104:11192-11196

Li B, Li Y-Y, Wu H-M, Zhang F-F, Li C-J, Li X-X, Lambers H, Li L (2016) Root exudates drive interspecific facilitation by enhancing nodulation and N-2 fixation. Proc Natl Acad Sci U S A 113:6496-6501

Limpens E, van Zeijl A, Geurts R (2015) Lipochitooligosaccharides modulate plant host immunity to enable endosymbioses. Annu Rev Plant Physiol Plant Mol Biol 53:311-334

Lundberg DS, Lebeis SL, Paredes SH, Yourstone S, Gehring J, Malfatti S, Tremblay J, Engelbrektson A, Kunin V, del Rio
TG (2012) Defining the core Arabidopsis thaliana root microbiome. Nature 488:86-90

Matsuoka H, Ohwaki Y, Terakado-Tonooka J, Tanaka F (2016) Changes in volatiles in carrots inoculated with ACC deaminase-producing bacteria isolated from organic crops. Plant Soil. doi:10.1007/s11104-015-2769-x

Mendes R, Garbeva P, Raaijmakers JM (2013) The rhizosphere microbiome: significance of plant beneficial, plant pathogenic, and human pathogenic microorganisms. Fems Microb Rev 37:634-663. doi:10.1111/1574-6976.12028

Mommer L, Visser EJW, Jv R, Hd C, Pierik R, Hd K (2011) Contrasting root behaviour in two grass species: a test of functionality in dynamic heterogeneous conditions. Plant Soil 344:347-360

Mommer L, Kirkegaard J, van Ruijven J (2016) Root-root interactions: towards a rhizosphere framework. Trends Plant Sci 21:209-217

Niu S-Q, Li H-R, Paré PW, Aziz M, Wang S-M, Shi H, Li J, Han Q-Q, Guo S-Q, Li J, Guo Q, Ma Q, Zhang J-L (2016) Induced growth promotion and higher salt tolerance in the halophyte grass Puccinellia tenuiflora by beneficial rhizobacteria. Plant Soil. doi:10.1007/s11104-015-2767-z

Ortíz-Castro R, Contreras-Cornejo HA, Macías-Rodríguez L, López-Bucio J (2009) The role of microbial signals in plant growth and development. Plant Signal Behav 4:701-712

Parniske M (2008) Arbuscular mycorrhiza: the mother of plant root endosymbioses. Nat Rev Microbiol 6:763-775

Peiffer JA, Spor A, Koren O, Jin Z, Tringe SG, Dangl JL, Buckler ES, Ley RE (2013) Diversity and heritability of the maize rhizosphere microbiome under field conditions. Proc Natl Acad Sci 110:6548-6553

Philippot L, Raaijmakers JM, Lemanceau P, van der Putten WH (2013) Going back to the roots: the microbial ecology of the rhizosphere. Nat Rev Microbiol 11:789-799

Pieterse CMJ, de Jonge R, Berendsen RL (2016) The soil-borne supremacy. Trends Plant Sci 21:171-173

Rajaniemi TK (2007) Root foraging traits and competitive ability in heterogeneous soils. Oecologia 153:145-152

Ravenek JM, Mommer L, Visser EJW, van Ruijven J, van der Paauw JW, Smit-Tiekstra A, de Caluwe H, de Kroon H (2016) Linking root traits and competitive success in grassland species. Plant Soil. doi:10.1007/s11104-0162843-Z

Reinhart KO, Tytgat T, Van der Putten WH, Clay K (2010) Virulence of soil-borne pathogens and invasion by Prunus serotina. New Phytol 186:484-495

Robroek BJM, Albrecht RJH, Hamard S, Pulgarin A, Bragazza L, Buttler A, Jassey VE (2016) Peatland vascular plant functional types affect dissolved organic matter chemistry. Plant Soil. doi:10.1007/s11104-015-2710-3

Roose T, Keyes SD, Daly KR, Carminati A, Otten W, Vetterlein D, Peth S (2016) Challenges in imaging and predictive modeling of rhizosphere processes. Plant Soil. doi:10.1007/s11104-016-2872-7

Roumet C, Urcelay C, Diaz S (2006) Suites of root traits differ between annual and perennial species growing in the field. New Phytol 170:357-368

Roumet C, Birouste M, Picon-Cochard C, Ghestem M, Osman N, Vrignon-Brenas S, K-f C, Stokes A (2016) Root structurefunction relationships in 74 species: evidence of a root 
economics spectrum related to carbon economy. New Phytol 210:815-826

Schnitzer SA, Klironomos JN, HilleRisLambers J, Kinkel LL, Reich PB, Xiao K, Rillig MC, Sikes BA, Callaway RM, Mangan SA, van Nes EH, Scheffer M (2011) Soil microbes drive the classic plant diversity-productivity pattern. Ecology 92:296-303

Schröder-Georgi T, Wirth C, Nadrowski K, Meyer ST, Mommer L, Weigelt A (2016) From pots to plots: Hierarchical traitbased prediction of monoculture biomass in a mesic grassland. J Ecol 104:204-218

Semchenko M, Saar S, Lepik A (2014) Plant root exudates mediate neighbour recognition and trigger complex behavioural changes. New Phytol 204:631-637

Siebenkäs A, Roscher C (2016) Functional composition rather than species richness determines root characteristics of experimental grasslands grown at different light and nutrient availability. Plant Soil 404:399-412

Stroheker S, Queloz V, Sieber TN (2016) Spatial and temporal dynamics in the Phialocephala fortinii s.l. - Acephala applanata species complex (PAC). Plant Soil. doi:10.1007/s11104-0152790-0

Sugiyama A, Bakker MG, Badri DV, Manter DK, Vivanco JM (2013) Relationships between Arabidopsis genotype-specific biomass accumulation and associated soil microbial communities. Botany-Botanique 91:123-126

Suriyagoda LDB, Lambers H, Renton M, Ryan MH (2012) Growth, carboxylate exudates and nutrient dynamics in three herbaceous perennial plant species under low, moderate and high phosphorus supply. Plant Soil 358:100-112

Tanaka N, Nishida S, Kamiya T, Fujiwara T (2016) Large-scale profiling of brown rice ionome in an ethyl methanesulphonate-mutagenized hitomebore population and identification of high- and low-cadmium lines. Plant Soil. doi:10.1007/s11104-016-2812-6

Tang X, Placella SA, Daydé F, Bernard L, Robin A, Journet E-P, Justes E, Hinsinger P (2016) Phosphorus availability and microbial community in the rhizosphere of intercropped cereal and legume along a P-fertilizer gradient. Plant Soil. doi:10.1007/s11104-016-2949-3
Thomson BC, Tisserant E, Plassart P, Uroz S, Griffiths RI, Hannula SE, Buee M, Mougel C, Ranjard L, Van Veen JA, Martin F, Bailey MJ, Lemanceau P (2015) Soil conditions and land use intensification effects on soil microbial communities across a range of European field sites. Soil Biol Biochem 88:403-413

Tibbett M, Ryan M, Kertesz MA (2012) Rhizosphere 3: where plants meet soils down-under. Plant Soil 358:1-5

Vacheron J, Combes-Meynet E, Walker V, Gouesnard B, Muller D, Moënne-Loccoz Y, Prigent-Combaret C (2016) Expression on roots and contribution to maize phytostimulation of 1-aminocyclopropane-1-decarboxylate deaminase gene acdS in Pseudomonas fluorescens F113. Plant Soil. doi:10.1007/s11104-016-2907-0

van Dam NM, Bouwmeester HJ (2016) Metabolomics in the rhizosphere: tapping into belowground chemical communication. Trends Plant Sci 21:256-265

Venturi V, Keel C (2016) Signaling in the rhizosphere. Trends Plant Sci 21:187-198

Vetterlein D, Doussan C (2016) Root age distribution: how does it matter in plant processes? a focus on water uptake. Plant Soil. doi:10.1007/s11104-016-2849-6

Visioli G, D'Egidio S, Sanangelantoni AM (2015) The bacterial rhizobiome of hyperaccumulators: future perspectives based on omics analysis and advanced microscopy. Frontiers in Plant Science 5

Wang P, Mommer L, van Ruijven J, Berendse F, Maximov TC, Heijmans MMPD (2016) Seasonal changes and vertical distribution of root standing biomass of graminoids and shrubs at a Siberian tundra site. Plant Soil. doi:10.1007/s11104-0162858-5

Weemstra M, Mommer L, Visser EJW, van Ruijven J, Kuyper TW, Mohren GMJ, Sterck FJ (2016) Towards a multidimensional root trait framework: a tree root review. New Phytol. doi:10.1111/nph.14003

Zhang D, Zhang C, Tang X, Li H, Zhang F, Rengel Z, Whalley WR, Davies WJ, Shen J (2016) Increased soil phosphorus availability induced by faba bean root exudation stimulates root growth and phosphorus uptake in neighbouring maize. New Phytol 209:823-831. doi:10.1111/nph.13613 